\title{
Shifting the Foundations of Confucian Political Thought
}

\author{
The Political and Its Demonic Aspects
}

Tang Junyi was well aware of the danger of political dogmatism stemming from Confucian traditions. In response, he rejected any idea of a traditionalist return to a pre-modern ethos of rule by virtuous elites, let alone "sages," which might undermine the emancipative potential of modernity. By the same rationale, he rejected the traditional ideal that politics should be evaluated by purely ethical or "humanistic" standards. He instead re-conceptualized the sphere of the political as a sphere of action which was, by necessity, governed by wills for power. Modern politics thus had only a derivative function with respect to the realization of "humanistic" values in society and would merely serve to secure the collective preconditions for the individual's quest for self-fulfillment by realizing his or her "inner sagehood."

Tang's Confucian civil theology assumes that the human being has an inherent potential to actualize sagehood, but also to unleash his or her lust for power. The reflection on the human being's struggle with his or her own lust for power is of fundamental importance to Tang's political thought in general. It is against this backdrop that he explored the formation of the human being's political and moral subjectivity in his two-volume monograph Cultural Consciousness and Moral Reason (Wenhuayishiyu daode lixing) from 1958 and in a number of articles published between 1950 and $1953 .{ }^{1}$ Here, Tang conceived of the human lust for power in a manner that was unprecedented in Confucian political thought. He now analyzed problems of power and evil with respect to politics and the individual's existence far more comprehensively than his Confucian

1 Cf. the following articles: "The Sources of Humanity's Evil" (first published in the weekly supplement of the Hong Kong Times [Xianggang Shibao 香港時報] in 1950; reprinted in Tang, Zhonghua renwen yu dangjin shijie bubian, Vol. 10, pp. 104-115); "Basic Knowledge about Humanistic Culture and Democracy” (first published in: Minzhu Pinglun, Vol. 3, No. 24 [December 1952]; reprinted in Tang, Renwen jingshen zhi chongjian, pp. 388-401); "Social Humanism and the Spirit of Democracy in China and the West" (first published in: Minzhu Pinglun, Vol. 4, No. 4 [January 1953]; reprinted in Tang, Renwen jingshen zhi chongjian, pp. 402-425). 
predecessors. This shift in his thought seems to have occurred gradually, for he published an article as late as July 1949 in which he still highlighted wellknown Confucian topics such as the human being's essentially social nature, the feasibility of harmonizing the community by fostering individual ethical self-cultivation, and the importance of relying on virtuous role models. At the time, however, he was already departing from these fundamental assumptions of traditional Confucian political anthropology. ${ }^{2}$

Tang's new theory of power plays a pivotal role in his philosophical project of renewing Confucianism under conditions of social modernization. He now contemplated power and its demonic aspects in politics in a way that suggests he was reacting to the famous passages of Max Weber's study on Confucianism in which he claims that Confucianism lacks a conception of radical evil. Among these passages, we find one about the Confucian state cult and Daoism, where Weber states that " $[\mathrm{b}]$ oth forms of religion lacked even the traces of a satanic force of evil against which the pious Chinese... might have struggled for his salvation."3

One should bear in mind that while Weber's study on Confucianism introduces the concept of evil as a religious-ethical issue, Tang took an interest in the notion of evil with respect to the political. He thus discussed the meaning and relevance of the lust for power in the context of political action in general. It is therefore enticing to relate Tang's reflection on power to the ideas about power and the nature of politics that Weber presents in his famous lecture Politics as a Vocation from 1919. Whether Tang actually reacted to Weber's writings is uncertain, but it seems rather unlikely that he was familiar with Weber's lecture. Nonetheless, a selective cross-reading of Weber and Tang reveals some illuminating intersections and disparities with regard to their concepts of power and the political.

Towards the end of Politics as a Vocation Max Weber draws the following conclusion:

Anyone who wishes to engage in politics at all, and particularly anyone who wishes to practice it as a profession, must become conscious of these ethical paradoxes and of his own responsibility for what may become of him under the pressure they exert. For, I repeat, he is entering

2 See his article "The Ideal Humanistic World" (first published in: Minzhu Pinglun [Hongkong], Vol. 1, No. 2 [July 1949]; reprinted in Tang, Renwen jingshen zhi chongjian, pp. 59-72).

3 Weber, The Religion of China: Confucianism and Taoism, p. 206 (for the German original, see Weber, Gesammelte Aufsätze zur Religionssoziologie, p. 490). 
into relations with the satanic powers that lurk in every act of violence. (...) Anyone who seeks the salvation of his soul and that of others does not seek it through politics, since politics faces quite different tasks, tasks that can only be accomplished with the use of force. The genius, or the demon, of politics lives in an inner tension with the God of love as well as with the Christian churches, and it is a tension that can erupt at any time into an insoluble conflict. ${ }^{4}$

Weber demands from politicians, particularly those who engage in politics as a vocation, that they perceive a specific political danger. This danger arises because the consequences-including the ethical consequences-of political acts inevitably elude safe calculation and control. Even more perilous is the fact that politics by definition involves the possibility of a forceful implementation of decisions that ultimately have unforeseeable outcomes. This fact, according to Weber, is especially distressing for those politicians who subscribe to a credo of ethics of conviction, which posits "that nothing but good comes from good and nothing but evil from evil." 5

In his Politics as a Vocation, Weber took a dig at politicians who are committed to such an ethics of conviction. Still, in the passage quoted above, Weber not only admonishes politicians, but all political actors, because they must face the danger inherent to the incalculable consequences of political decisions and should therefore acknowledge that one cannot rely on claims to pure convictions or good intentions to achieve good ends in politics. As Weber understands it, a specifically political danger arises from the inevitable use of certain means which are characteristic of politics, namely those involving the exertion of power and force. ${ }^{6}$ Politics, according to Weber, means "to strive for a share of power or to influence the distribution of power, whether between states or between groups of people contained within a state."7 There are two distinct aims that motivate people to strive for power in politics and other

4 Weber, The Vocation Lectures. "Science as a Vocation" "Politics as a Vocation," p. 90 (for the German original, see Weber, Politik als Beruf, p. 64).

5 Weber, ibid., p. 86 (Weber, Politik als Beruf, p. 6o).

6 Weber, ibid., p. 86 (Weber, Politik als Beruf, p. 6o).

7 Weber, ibid., p. 33 (Weber, Politik als Beruf, p. 8): For Weber, power is "the probability that one actor within a social relationship will be in a position to carry out his own will despite resistance, regardless of the basis on which this probability rests." See Weber, Economy and Society, p. 53. This passage is followed by Weber's often quoted amendment that the concept of power is "sociologically amorphous" (ibid.). 
social relations. Both involve the longing for power "as a means in the service of other goals, whether idealistic or selfish, or ... power 'for its own sake' ... so as to enjoy the feeling of prestige that it confers." ${ }^{8}$ In conceptualizing the quest for power as a sustaining element of politics, Weber places his focus on the state. From this perspective, he conceives of a peculiar relation between power and violence. Insofar as the quest for power is directed at the state, it involves the means of power that is specific to the state and which only the state may use in a legitimate manner: the use of coercive force. ${ }^{9}$

Political activity, in Weber's conceptualization, entails an element of irrationality, for those who apply specifically political means (i.e. coercive power, violence) cannot foresee whether or how they themselves will be transformed by the "demonic" impact of these means. In Weber's view, it is characteristic of politics that not only political activity as such, but also its effects on the world and the political actors themselves may in the end contradict ethical standards. In fact, Weber emphasizes that "the ultimate product of political activity frequently, indeed, as a matter of course, fails utterly to do justice to its original purpose and may even be a travesty of it."10 It is exactly this self-awareness of the potential of a political "travesty" which marks the peculiarity of politics vis-à-vis the realm of ethics and religion. What is more, whereas the ethics of capitalism and its inherent goal to accumulate profit have been ushered into Western society (albeit inadvertently, as Weber assumes) by Protestant asceticism and its rejection of the world, the looming conflicts between the "satan of politics" and the "Christian God" remain "insoluble." As Weber insists, politics indeed has its own reservoir of satanic powers."1

In Politics as a Vocation Weber harshly admonishes the proponents of what he calls a pure ethics of conviction for their inability to act in a politically responsible way. Whoever is unable to acknowledge that the credo of an ethics of conviction does not amount to a truism with respect to political action is "in fact a mere child in political matters." ${ }^{12}$ The political immaturity of proponents of an ethics of conviction is manifest in their belief that "the ethical demands

8 Weber, The Vocation Lectures. "Science as a Vocation" "Politics as a Vocation," pp. 33-34 (Weber, Politik als Beruf, p. 9).

9 Weber, Wirtschaft und Gesellschaft, p. 29; see also: Lenk, "Max Weber," pp. 310-311.

10 Weber, The Vocation Lectures. "Science as a Vocation" "Politics as a Vocation," p. 78 (Weber, Politik als Beruf, p. 53).

11 See Von Ferber, Die Gewalt in der Politik, pp. 68-75.

12 Weber, The Vocation Lectures. “Science as a Vocation" "Politics as a Vocation," p. 86 (Weber, Politik als Beruf, p. 6o). 
made on politics" may remain untainted by the fact "that politics operates with a highly specific means, namely, power, behind which violence lies concealed". ${ }^{3}$

To make things worse, those who subscribe to a pure ethics of conviction are also capable of applying violence as a means to realize ethical demands. Indeed, their fatal failure to cope with reality shows itself at the very point where they have to face the "problem of justifying the means by the ends," and hence the use of violence. Here, there is some likelihood that "the representatives of an ethics of conviction suddenly become chiliastic prophets," who call upon their followers to participate in "the very last use of force" in order to overcome an insufficiently ethical world altogether: "[T] he man who embraces an ethics of conviction is unable to tolerate the ethical irrationality of the world." Believers in pure ethics of convictions are dangerous, because they are unable to grasp the diabolic threat that accompanies the use of violence as a means of politics, and are thus inclined to sanctioning all means of violence in the attempt to attain salvation. ${ }^{14}$

In contrast, the type of professional politician Weber favored should opt for the maxim of an ethics of responsibility. Weber, in fact, considered the two maxims of an ethics of conviction and an ethics of responsibility to be "irredeemably incompatible,"15 although he still warned that the ethics of conviction and the ethics of responsibility should not be treated as "absolute antitheses." They are, after all, "mutually complementary, and only when taken together do they constitute the authentic human being who is capable of having a 'vocation for politics."'16 In conclusion, Weber called on the professional politician to endure this ethical tension with the "trained ability to scrutinize the realities of life ruthlessly, to withstand them and to measure up to them inwardly."17 In doing so, he or she should not count on the "goodness and perfection" of their fellowmen, but must reckon with the "average human failings." ${ }^{18}$ As for the Confucian individuals, they fail to live up to this demand, as Weber assumes. Instead, they believe that the world they live in is "the best of all possible worlds" and remain convinced that "human nature was disposed

13 Weber, ibid., pp. 80-81 (Weber, Politik als Beruf, p. 55).

14 Weber, ibid., p. 85 (Weber, Politik als Beruf, p. 59).

15 Weber, ibid., p. 83 (Weber, Politik als Beruf, p. 57).

16 Weber, ibid., p. 92 (Weber, Politik als Beruf, p. 66).

17 Weber, ibid., p. 91 (Weber, Politik als Beruf, p. 65). The reference to ruthlessness does not indicate that Weber favored a type of politicians who are driven by their lust for power. For Weber, the professional politician should not strive for power solely for the sake of power: Ibid., p. 78 (for the German original, see Ibid., p. 52).

Weber, ibid., p. 84 (Weber, Politik als Beruf, p. 58). 
to the ethically good" and "[m]en... capable of unlimited perfection ... were in principle adequate for fulfilling the moral law."19

Similar to Max Weber's approach, Tang Junyi identified the core dogma of Confucian religiosity as the belief in the inborn ability of human beings to attain moral perfection. But in stark contrast to Weber's depiction of Confucianism, Tang's Confucian civil theology does not support the conviction that the human being is capable of fulfilling the "moral law" by merely following conventional ethics. Tang, as we have seen, conceptualized self-cultivation as a multifarious effort that comprises, above all, moral self-reflection, but also forms of practical engagement in politics and society at large. The individual's impetus for such practical engagement is not purely ethical. On the contrary, Tang called on individuals to consider their own egotistic side as a crucial impetus for their practical, and most of all political, engagement.

As Tang saw it, the Confucians in pre-modern times also addressed such a call to the practitioners of self-cultivation, but they insufficiently grasped the human lust for power. The Confucian "worthy" and "sages" hardly took notice of the fact that the "transformation through the teachings," which they wanted to bestow on humanity, could be "fundamentally" resisted by the human lust for power. ${ }^{20}$ Nor did they reckon with the "deepest selfish desire" of the human being, namely, the "pure will for power" (chuncui de quanli yizhi 純粹的權力 意志). Like Weber, Tang defined this pure will for power as the will to wield power solely for the sake of wielding power. It is in this sense that the pure will for power culminates in a decision about "leaving alive or killing, giving or taking, rewarding or punishing." 21

19 Weber, The Religion of China: Confucianism and Taoism, pp. 227-228 (for the German original, see Weber, Gesammelte Aufsätze zur Religionssoziologie, p. 514).

20 Tang, Renwen jingshen zhi chongjian, p. 396. Tang's critique is echoed in Chang Hao's famous essay "Dark Consciousness and Democratic Tradition." Chang discusses different expressions of pessimistic notions of human nature and the human being (hence the "dark consciousness" [you'an yishi 幽暗意識]) in Western and Chinese contexts and concludes that overall, Chinese philosophers gave only insufficient thought to the "dark" side of man. Chang's essay is highly stimulating in many respects, but regrettably does not discuss Tang's concept of evil. The only part of Chang's book You'an yishi yu minzhu chuantong which deals with Tang's philosophy is a general overview found in the Chinese translation of Chang's English article "New Confucianism and the Intellectual Crisis of Contemporary China”; see Zhang (Chang Hao), You'an yishi yu minzhu chuantong, pp. $3-32$; see also pp. $33^{-78}$.

Tang, Renwen jingshen zhi chongjian, p. 395. 
Among the "satanic" aspects of the pure will for power is the inclination for cruelty. Tang distinguished in his analysis different forms and degrees of cruelty. Their most despicable manifestation is reached whenever a person derives deep satisfaction from observing another's suffering after insidiously harming him or her through planned, "rational" action, without revealing who the perpetrator was. ${ }^{22}$ The pure will for power may indeed apply rational means to achieve this end, but any analysis that disregards the irrational side of the lust for power inevitably falls short. The Marxist approach that examines the will for power through an analysis of socioeconomic structures and a calculation of interests is therefore misleading according to Tang. By way of example, Tang elaborated on the fact that there are cases where human beings apply a degree of cruelty which stands in no rational relation to the economic interests at issue. Furthermore, in the course of a conflict in which both parties suffer great material losses, it is possible that the one party whose losses are less severe still gains some satisfaction from observing that their opponent has lost even more. ${ }^{23}$ Here, the pure will for power elevates destruction for destruction's sake to a virtue of "satan" (sadan 撒旦). Moreover, in becoming satanic, the human consciousness lifts itself above the worthies and sages, who are now the object of contempt. ${ }^{24}$

Tang's insights into the human lust for power and its potential for cruelty contain several references to "satan," but also to "god" (shangdi 上帝) or "father" $\left(f u\right.$ 父). ${ }^{25}$ It is difficult to explain why Tang used such terms. To be sure, he did not introduce an ontological notion of evil here, and this also holds true for an allegorical passage in which he claimed that the satan is a "satan in the human mind," who "stands at our side at any moment."26 While Tang was not interested in situating evil ontologically, he did explain that it only emerges when

22 Tang, Wenhua yishi yu daode lixing, pp. 564-565.

23 Tang, Zhonghua renwen yu dangjin shijie bubian, Vol. 10, p. 111.

24 Tang, Renwen jingshen zhi chongjian, p. 395. It seems significant that Tang does not refer to the subject of the lust for power solely with the pronoun of the third person singular or by general references to "the human being" or "the lust for power." These types of references would insinuate a safe distance between the "I" of the interpreter and his readers, on the one hand, and the subject of the lust for power under scrutiny, on the other. Instead, Tang often uses personal pronouns of the first person ("I," "we") in this context. He apparently had no intention to grant any exceptions from the potential affliction by the lust for power, thereby denying any pre-established moral superiority to himself or his readers.

25 Tang, Zhonghua renwen yu dangjin shijie bubian, Vol. 10, p. 113.

26 Ibid., p. 112. 
"human nature cannot completely reveal itself." ${ }^{27} \mathrm{He}$ consequently suggested that the full actualization of one's human nature, in which one has "exerted the mind" and "knows human nature," is certainly without evil. Yet, the individual's self-absorption with the lust for power seems to belong to human nature, too, and only momentarily dissipates at the stage of an ephemeral, sagely actualization. There is a peculiar change in perspective here, inasmuch as the lust for power is not seen as the result of an unrestrained display of human nature (in terms of instincts and passions), but, on the contrary, as a symptom of the incomplete manifestation of human nature (xing) itself. According to Tang's civil theology, this failure is due to the fact that the individual is still in a state of self-imposed constraint vis-à-vis his or her true nature.

The references to satan and god seem to be more allegorical than theological in nature. Tang rarely used these allegories, and when he did, he did so without any specific relation to theological concepts from Jewish-Christian traditions. Significantly, there are passages in which he directly combined the terms "satan" and "god" with Confucian terms like (good) "innate knowing" (liang zhi) and (evil) "selfish desires" (si yu 私欲), without any elucidation of their mutual relation..$^{28}$ The somewhat enigmatic notion of selfish desires does not denote a specific set of desires or behavioral impulses, but rather a particular, i.e. egotistic, way in which individuals try to satisfy their needs. It is in this context that Tang depicted the source of evil as an "unrestricted expansion of the will for power inside the substratum of the human mind," ${ }^{29}$ which he thus identified with the pure will for power.

For Tang, evil, as it becomes manifest in the pure will for power, is a problem of human subjectivity. Even though he conceded that social structures and orders can effectuate evil results, he rejected the idea that human subjectivity and free will are completely subdued by social structures. He thus insisted that social systems should be regarded as if they were formed and validated by the human mind.$^{30}$ Although he did not explicitly refer to the concept of freedom in this context, it is clear that his concept of the pure will for power is closely related to the free will. Evil is therefore neither a necessary consequence of economic, political, or social structures, nor an inevitable epiphenomenon

27 Ibid., p. 107.

28 Ibid., p. 113. In this context Huang Zhaoqiang's discussion of Tang's Rensheng zhi tiyan is instructive: Huang quotes Tang's statement that he takes the term "deity" (shen 神) to refer to the human being's "immanent spirit;" see Huang, Xueshu yu jingshi-Tang Junyi de lishi zhexue ji qi zhongji guanhuai, p. 33 .

29 Tang, Zhonghua renwen yu dangjin shijie bubian, Vol. 10, p. 108.

30 Ibid., p. 104. 
of the human being's animalistic nature. In fact, the manifestation of a pure will for power lifts the human being beyond his or her animalistic nature: Because humans, unlike animals, are self-conscious and possess a "mind," they have an insatiable lust for power, wherein the yearnings exceed the satisfaction of mere animalistic and materialistic needs. Tang elaborated on this notion of an insatiable lust for power by distinguishing between a pure "will for power" (synonymously, a "lust for power" quanli yu 權力欲), and an "unconscious" (bu zijue 不自覺) will for power. The latter, constituted by life-preserving instincts like the sense of hunger and the sexual drive, is common to both human beings and animals. It targets particular objects and can consequently be satisfied. It is hence "restricted" and not "necessarily" evil. ${ }^{31}$

In Tang's view, it was the blind spot in the political thought of pre-modern Confucians that they overlooked the satanic, irrational presence of a lust for power, which is inherently insatiable and condemns the individual to a life of compulsive repetition (to use a Freudian expression). Tang wanted to eliminate this blind spot, for there is a lot at stake:

[If] people do not recognize the existence of this evil [of the pure lust for power], they also cannot truly understand what socio-political systems and cultural forms [actually are] that really contain evil. Neither can they truly understand what socio-political systems and cultural forms are the best. ${ }^{32}$

It therefore will not suffice to put one's confidence solely in the good deeds of the worthies and sages, who validated "the values of human existence and culture" (i.e. guiding values in ethics, religions, science, arts, education, and the economy). After all, the pure will for power may completely reject all the values and deeds of the worthies and sages at any time. ${ }^{33}$ What is more, the pure will for power is neither a mere pathological phenomenon, nor a demonic aberration of the human being, but rather a "natural" incitement for political action. As Tang argues, the very quest for political power marks the core of political history, and the lust for power is a motivational force which drives history. ${ }^{34}$

Nevertheless, striving for power is not an exclusively political phenomenon. As Tang's theory of power posits, power itself as well as the lust for power are sociologically amorphous in the sense of Max Weber. They become manifest,

\footnotetext{
31 Ibid., pp. 109, 111.

32 Ibid., p. 110.

33 Tang, Renwen jingshen zhi chongjian, p. 395 .

34 Tang, Wenhua yishi yu daode lixing, p. 182.
} 
to cite examples provided by Tang, in a "concealed" manner in the mutual depreciation of scholars, writers and artists, in the dogmatic claims to truth by religious leaders and moral experts, and in people's indulgence in debauchery and hunger for profit. Individuals may even become captivated by the lust for power when they strive for the values of truth, beauty, and good. ${ }^{35}$

\section{Introspection in the Will for Power}

Tang defined politics, like Weber, on the basis of its specific means of power and force. He also related the function of politics conceptually to the sphere of the state. The function of politics, namely, is to ensure the existence of the state and to uphold, if necessary by the use of force, the social order. ${ }^{36}$ But unlike Weber, Tang tried to define politics with respect to its goal (its "essence," in the words of Tang), which he thus defined as achieving "an arrangement for a reasonable distribution of power." From this perspective, politics can be conceptualized as a sphere in which one may strive for the good. ${ }^{37}$ This does not mean, however, that there was or could be a superior type of politics which is completely devoid of struggles for power. On the contrary, politics in general is characterized by particularly vehement manifestations of wills for power, including the irrational lust for power. After all, as Tang suggested, political actors must strive for power. They are thus distinct from scholars, writers, artists, and religious leaders, who may at times orientate their actions toward the goal of gaining power, but may also go about their affairs without striving for power. In contrast, the political actors who want to attain a reasonable arrangement of power in society do not have such a choice, for they need power if they want to achieve their goals. ${ }^{38}$

Tang obviously made good on the call of the manifesto of 1958 for a distinction between moral and political subjectivity by conceptualizing politics as a particular sphere of activity in which the actors inevitably strive for, and make extensive use of, power (including the legitimate use of force in terms of state power). In the course of struggling for power and force, and by making use of these means, political actors always run the risk of being severely afflicted by these means psychically and morally. Similar to Weber, Tang reflected on this sort of self-endangerment of political actors by call-

35 Tang, Zhonghua renwen yu dangjin shijie bubian, Vol. 10, p. 112.

36 Tang, Renwen jingshen zhi chongjian, p. 390.

37 Tang, Zhonghua renwen yu dangjin shijie bubian, Vol. 10, p. 113.

$3^{8}$ Ibid., pp. 113-114. 
ing attention to the fact that the actors' own lust for power may grow "easily" and in a "hidden" way. The danger of becoming completely absorbed by the lust for power is particularly great in the political sphere, since politics is essentially concerned with the arrangement of power, and it thus provides the "deepest" satisfaction for the lust for power. ${ }^{39}$ It is for this reason that Tang conceived of politics and political activity in terms of the exposure of actors to the "satanic" potential of their own lust for power.

Even though Tang conceptualized politics with an emphasis on irrational elements that are deeply rooted in the human lust for power, he also reflected on political action in terms of opportunities for actors to express their "innate" capacity for goodness. Hence the lust for power, though belonging to the natural endowments of the human being, does not completely dominate political action. To argue this crucial point, Tang set out to establish that human beings are not held captive to the lust for power, but may lift themselves above it. He therefore undertook an analysis of the consciousness of power-seeking individuals - an approach which entails a phenomenological introspection into the subjective consciousness as well as deeper psychic layers.

It is safe to say that Tang, in his analysis, had neither predecessors nor successors in Confucian thought. The structure of the analysis is such that it reveals an inner dialectic of the individual will for power, which is related to the famous master-servant dialectic from Hegel's Phenomenology of the Spirit. ${ }^{40}$ Yet Tang did not mention Hegel in this context, perhaps because he not only felt that the reference was all too obvious-he introduced the figures of "master" (zhuren 主人) and "servant" (or "slave"; nuli 奴隸)—but also potentially misleading. ${ }^{41}$ Be that as it may, the focal point of Tang's phenomenology of the

39 Ibid.

40 Tang, Wenhua yishi yu daode lixing, pp. 185-197. In his article "The sources of humanity's evil” (see Tang, Zhonghua renwen yu dangjin shijie bubian, Vol. 10, pp. 104-115), Tang related the analysis of the pure will for power rudimentarily to the dialectical structure of the individual's struggle for recognition.

Tang, Wenhua yishi yu daode lixing, pp. 189, 192. Liu Guoqiang does not elaborate on the proximity of Tang's analysis to Hegel's phenomenology of self-consciousness that introduces the notion of a struggle for recognition between "master" and "servant." As a consequence, Liu interprets Tang's thought as if Tang were to present a dogma which states that human self-consciousness naturally tends to transcend the (empirical) "self;" see Liu, "Tang Junyi de zhengzhi zhexue," pp. 59-61. The fact that the notion of a (self-) transcending self-consciousness is fundamental to Tang's thought is also stated by Shun Kai Kevin Cheng in: Cheng, Karl Barth and Tang Junyi on the Nature of Ethics and the Realization of Moral Life: A Comparative Study, pp. 231-236, 247-248. Nevertheless, it seems problematic to interpret Tang's analysis of the human consciousness of power 
lust for power is the assumption that individuals, while giving in to the lust for power, may still attain an enlightening realization of their "true" moral nature.

For Tang, the human lust for power is first and foremost a desire to subdue others. ${ }^{42}$ This desire is initially sustained by a self-referential "blind adherence" to power on the part of the empirical self (the "real self"). However, selfconsciousness is not restricted to the empirical self-it is a "doubled self" which is revealed in the will for power itself: ${ }^{43}$ Apart from the empirical self, there is the "transcendent self," which is manifested in the willingness to risk one's life (i.e. the life of the empirical self) in the struggle for power. The transcendent self strives to overcome the opponent's lust for power and force the opponent to acknowledge it as the superior will. The "very first impulse" of the transcendent self to subdue the opponent consists in a yearning to gain such recognition. This necessarily implies that the transcendent self initially recognizes the opposing consciousness as equal, for otherwise the recognition (by an already inferior opponent) would be meaningless. ${ }^{44}$ Indeed, the depth of the satisfaction which the will for power attains by subduing an opposing will depends upon the strength of the opponent. ${ }^{45}$ Nevertheless, once the opposing will is forced into submission, its recognition cannot continue to satisfy the victorious consciousness of power, because the latter no longer recognizes the inferior will as an equal. ${ }^{46}$ At this point, the superior consciousness experiences a "great emptiness" (da kongxu 大空虛):

When, therefore, what is regarded as the human being's will for power reaches [a point where it has] nothing left to achieve and [thus] perceives that there are no more human wills worthy of its antagonism, worthy of fighting [it] for supremacy, it will turn around and perceive a great emptiness. This was so when Liu Bang could not help crying when [reciting] "Now that my might rules all within the seas;"47 and it was also so when Alexander, after unifying Persia and reaching India, gazed into the vast

without taking note of his dialectical approach. For an insightful critique of his notion of (self-)transcendence, see Chan, "Tang Junyi: Moral Idealism and Chinese Culture," pp. $316-318$.

42 Tang, Wenhua yishi yu daode lixing, p. 182.

43 Ibid., pp. 182-184.

44 Ibid., pp. 183-185.

45 Ibid., p. 186.

46 Ibid., p. 187.

47 Tang quotes here from the Song of the Great Wind, which is traditionally attributed to Liu Bang (canonized as Emperor Gao of Han; 256-195 BCE). Liu Bang is said to have written the song upon returning to his ancestral village after suppressing a rebellion in 196 вСE. 
sea shedding tears. Hence, the will for power, true to its original nature, is in the end unable to find satisfaction. (...) Now that the constant surrendering of an antagonistic will must be continued, an antagonistic will is constantly being discovered, sought out and established, right until every antagonistic will is forced into submission, up to the point where [the will for power] arrives at the great emptiness. ${ }^{48}$

The dialectic structure of the recognition-based struggle for power propels self-consciousness into an idling cycle. Within this cycle, the pure will for power, which is by definition insatiable, restless and finally aimless, is perpetually trapped. But human self-consciousness is not dully tied to this cycle and may eventually overcome the blindness of the will for power at the very point where it gains insight into its inner self-contradiction as a will for power. The tears of Liu Bang, the founder of the Han Dynasty, and Alexander the Great testify to the awareness that the will for power cannot further expand into the "great emptiness" and is hopelessly trapped by its inner restlessness. At this point, a "reversal" towards moral consciousness may take shape, which Tang elucidated in the following step of introspection in the dialectic of the consciousness of power. Toward this end, he again reflected on the victorious will for power and on the consolidation of its rule once victory has been attained.

As a point of departure, Tang established the fact that the victorious will must secure the obedience of the conquered will in order to safeguard its ruling position. If the victorious will manifests itself solely as an irrational, animalistic drive, it cannot expect obedience in the long run, for this requires the issuance of orders in a regular, normalized manner and form. The obedience it obtains is even deeper if it acquires honor and wealth during the course of its rule, which in turn earns it the admiration of the conquered will. Yet in striving for honor and wealth, it depends, nonetheless, on the conquered will to recognize the merit of such striving. What is more, the quest for honor and wealth involves objects that cannot be enjoyed by all wills to the same degree. They are the privilege of the ruling will, which inevitably gives rise to envy. The ruling will, therefore, cannot secure the obedience of the inferior will in a complete and lasting way. For this reason, the ruling will is compelled to conceal its “selfishness" ( $\operatorname{sixin}$ 私心). 49

The above translation is Burton Watson's; see Minford, Classical Chinese Literature. An Anthology of Translations Volume 1: From Antiquity to the Tang Dynasty, p. 415.

48 Tang, Wenhua yishiyu daode lixing, p. 187.

49 Ibid., pp. 188-197. 
Permanent and "deep" obedience may only be established if the admiration of the inferior will is not due to the victorious will's possession of an external object, but is directed at something internal to the victorious will. Inasmuch as the object of admiration is not extrinsic, material and quantifiable, but intrinsic to the will (i.e. related to inner qualities), it remains, at least in theory, accessible to all the wills. Part of these inner qualities is the ability to recognize and realize values related to truth and beauty. Because this specific ability does not require the possession of external, limited goods, the inferior will does not envy the victorious will, but rather recognizes its exemplarity stemming from a superior ability to realize certain values. Yet, the display of this ability in truth and beauty still involves goods that are external to the victorious will..$^{50} \mathrm{At}$ this stage, it therefore still receives no recognition solely for its own sake, but for the external values that it creates and embodies. Such recognition does not reflect the ultimate degree of recognition - the latter is only attained if the victorious will displays an exemplarity due to qualities that are completely inside the will itself and hence represent the highest degree of universality (in terms of being theoretically attainable by any will)..$^{51}$ This pertains, most of all, to "moral values" that become manifest within the victorious will and may thus be universally recognized as "objective values." ${ }^{\text {2 }}$ Significantly, the deepest, i.e. voluntary, obedience is therefore achieved only by those who take up their position of power as a "moral personality." ${ }^{3}$ Tang highlighted this change of perspective towards the moral person as a "reversal" of the consciousness of power:

The great emptiness, which [exists] after obtaining absolute power, causes the human being to perceive that since there is nothing to which power [may] be extended, [the absolute power] must also necessarily be reversed. Through such a reversal, the transcendent self reveals [itself]. In this way, [the absolute power] can also do an about-face and have compassion for the antagonist that it killed. It [can] even protect and care for the antagonists who surrendered; or it [can] divide power with human beings whom it initially ignored, like enemies who surrendered to it and those who are under its command. If the will for power, therefore,

\footnotetext{
$50 \quad$ Ibid., pp. 197-200.

51 Ibid., p. 201.

52 Ibid., p. 202.

53 Ibid., p. 203. The reference to Kant is obvious; see also He, Ruxue yu xiandaiminzhu, p. 119.
} 
truly aspires to find peace, it will necessarily transform [itself] into or initiate a sort of moral will. ${ }^{54}$

Tang obviously assumed that once the will for power subjugates its antagonist, it falls into an abysmal idling cycle of restlessness. This compels it to perpetually repeat its power-driven behavior, even though it is already in a situation where no equal antagonist can emerge. The only escape from this "great emptiness" is the self-transformation ("reversal") of the will for power into a "sort of moral will." The will for power thus seems to be capable of overcoming itself and predetermined to do so exactly because, as long as it requires an antagonistic will, it inevitably fails to satisfy its claim to recognition from others in a self-sufficient manner.

However, this auto-therapeutic transformation is extremely demanding. It requires self-consciousness to fully grasp the dialectical mode of its own will for power and to recognize the inner contradiction of a will for power which collapses upon confronting a dead end, namely, the intrinsic impossibility of its own satisfaction. Tang, in fact, posited here that human beings, due to the very nature of their lust for power, ultimately strive to overcome once and for all an "inner," psychic and intellectual state of restlessness by realizing their moral subjectivity. Significantly, Tang had dealt with the topic of eradicating the pull of the instincts and the lust for power in his reflections about the sublime realm of sagehood, where the chasms of subject and object, self and others, I and self are extinguished. It is therefore likely that his reference to the "transcendent self" and the initiation of "a sort of moral will" in the passage quoted above alludes to the state of sagehood as it unfolds in liang zhi.

With respect to the mundane life situation of the empirical self, the conclusion presents itself that since the state of attaining sagehood (or liang zhi) is impermanent, the self-transforming reversal of the will for power also does not produce a permanent state of existence. Otherwise, by overcoming the absorption of the self in power-driven behavior, the individual could terminate the totality of his or her political life once and for all. But the promise of an apolitical life, which is free from the impact of power and power-seeking, is not what Tang had in mind here. The "reversal" rather constitutes a recurrent task in the individual's moral endeavors. This understanding of moral self-reflection is highly optimistic. It entails the expectation that the ego's introspection amounts to a self-liberation from the idle cycle of insatiable power-seeking. The ego is seen here as a self-consciousness capable of learning from its 
experience as a will for power and, consequently, of "rationally" choosing a superior mode of self-fulfillment. Given this capacity to dominate its irrational side, the ego advances to a position of self-mastery in which it no longer strives for the recognition of others anymore and therefore can refrain from futile power-seeking. To paraphrase Freud, the ego is thus portrayed as a master in its own house. Tang's notion of an active initiation of the reversal also stands in stark contrast to Schopenhauer's philosophy of the will in The World as Will and Representation. It remains open to debate whether Tang's philosophy of the will for power was at all informed by Schopenhauer. Nonetheless, Tang's notion of self-cultivation clearly contradicts Schopenhauer's assumption that insight into the workings of the will only liberates the human being to resignation and renunciation and merely offers the peace and consolation that comes from the knowledge that whatever befalls a person is inevitable and irreversible.

Tang's analysis of the will for power has repercussions for his reflection on the foundations of socialization. As the foregoing analysis of the dialectic suggests, even in constellations that are characterized by power struggles, individuals remain, albeit unintentionally, within the horizon of the moral will and moral subjectivity. Hence, the individual's socialization ultimately rests not solely on a rational calculus of self-interests, but on the moral implications of the antagonistic structure of the struggle for recognition. Tang's explanation of the foundation of the social state of existence thus differed from contract theories in Western philosophy, which place much more emphasis on the individuals' (enlightened) self-interests as a basis for their willingness to participate in collective life. It is therefore hardly surprising that Tang took issue with the Hobbesian theory of a social contract, as well as mainstream contract theories, by stating that such an approach conveys a one-sided and pessimistic image of human nature. He critically added that since these theories depict the individuals' mutual recognition solely in terms of contractual provisions, such intersubjective recognition is inevitably restricted in terms of scope and duration. ${ }^{55}$

At first glance, there seems to be congruence between Tang's and Hegel's theory of recognition, which also took a critical stance towards contract theories. As Axel Honneth demonstrates, Hegel tried to show that "subjects can, on their own, reach a conflict resolution based on law (as formulated in the

55 Tang, Renwen jingshen zhi chongjian, pp. 392, 416-417; see also Tang, Wenhua yishi yu daode lixing, pp. 245-249. On Tang's criticism of social contract theories, see also Liu, "Tang Junyi de zhengzhi zhexue," p. 65. 
social contract) even under conditions of hostile competition." With this aim in mind, Hegel, in contrast to contract theories, conceptualized the adoption of the social contract not as an intellectual construct which claims theoretical necessity, but as an "empirical necessity" arising from the social constellation itself. Hegel, according to Honneth, argues "that all human coexistence presupposes a kind of basic mutual affirmation between subjects" which entails a "moral potential evidenced in the individual's willingness to reciprocally restrict their own spheres of liberty." Thus, an "implicit form of legal consciousness" takes shape here. As Hegel assumed, individuals are ready to make the transition from the natural state to the social state "at the moment in which they become conscious of their prior relationship of recognition."56 Hegel therefore, like Tang, attempted to uncover the potential for ethical relations in the midst of present hostilities relating to empirical struggles for recognition - a potential which Hegel understood to be foundational for the legal arrangement of coexistence.

There is, nonetheless, a fundamental difference between Hegel's and Tang's approaches insofar as Tang, in the end, did not anchor this ethical potential within intersubjective relations, but within the subjective inwardness of the individual who gains insight into the spiritual necessity of a "reversal." It is certainly no coincidence that Tang exemplified the formation of moral subjectivity, which arises from the power struggle for recognition, with the solitary figures of Liu Bang and Alexander the Great. Tang conceptualized the individual's willingness to restrain his or her own lust for power and engage in an intersubjective practice of self-cultivation, ethical life, and legal coexistence as stemming from the subjective mind's own inner exploration. Indeed, it is in this existentialist sense that he interpreted the Mencian notion that a man should "give full realization to his mind (jin qi xin)" in order to "understand his own nature (zhi qi xing)." Yet, Tang's and Hegel's ideas are in conformity in another important respect: Both denied that the subjectivity of the individual arises from a higher, pre-existing ethical harmony. In fact, they each suggested that the formation of subjectivity occurs only when traditional ideas of a substantive unity or harmony are shattered.

56 All quotes from Honneth, The Struggle for Recognition: The Moral Grammar of Social Conflicts, pp. $42-43$. 


\section{The Moral Dimension of the Political Will}

Tang Junyi had no intention of playing down the "satanic" impetus of the human lust for power as a mere prelude to the unfolding of moral subjectivity. His interest in the lust for power indeed centers on the question of how moral subjectivity emerges in the midst of the omnipresence of the lust for power in human existence. From this perspective, we may understand Tang's speculation as addressing a question which we may phrase in allusion to his allegorical language: How do we reconcile the Confucian belief in human nature, in which everyone can become a sage like the legendary emperors Yao or Shun, with the realization that in fact everyone wants to become a Liu Bang or Alexander the Great (if only in their daily struggle for prestige or wealth)? Tang did not content himself with the mere claim that individuals, even if they are involved in acts of utter cruelty, may still experience sudden moments of a "disconcertment within the inner spirit" which indicate that moral intuition ("innate knowing") is not absent altogether. ${ }^{57} \mathrm{He}$ wanted to bolster this assertion with his analysis of the lust for power. His phenomenological introspection into the workings of its inner dialectic should demonstrate that individuals, who by all appearances are completely captivated by their lust for power, still accord with (self-)restrictions on their drive for power that point them in the direction of morality. The lust for power is hence intrinsically related to the formation of moral subjectivity. Tang consequently refrained from depicting morality solely as an antipode of the lust for power that tries to restrain, subdue, or even extinguish it. Morality is rather the ultimate escape that comes into view even as the will for power faces the "great emptiness," i.e. the stagnancy of its dialectical movement, which is in terminal self-contradiction.

However, the "great emptiness" itself is clearly not the same as the vacuity of the "void potency [and] bright awareness" (xu ling ming jue), which the individual achieves as the state of mind in which moral intuition (liang zhi) occurs. Neither Liu Bang nor Alexander the Great actualizes liang zhi and becomes a sage in the moment of despair when faced with the paralyzing emptiness after the last victory. The "great emptiness" is not identical with the "void potency," which emerges from the successful practice of self-fulfillment. Whereas such practice leads the human spirit to the vacuity of the "void potency [and] bright awareness," the engagement in power struggles only produces the consuming emptiness of a restless lust for power.

The distinction between the "great emptiness" and the vacuity of the "void potency [and] bright awareness" is also crucial because it indicates a line of

Tang, Wenhua yishi yu daode lixing, p. 565 . 
demarcation between a Nietzschean conception of power and morality and Tang's conceptualization. When solely considering Tang's reflection about the formation of moral subjectivity in the "great emptiness," a quasi-Nietzschean conclusion seems to suggest itself: Moral subjectivity ultimately evolves out of a frustrated, pure will for power. Even though such a conclusion does not entail the idea of a genealogical development of power vis-à-vis morality in human history, it still bears a Nietzschean imprint. As a matter of fact, Tang remained skeptical about (Confucian) claims that traditional ethical relations and practice (i.e. of self-cultivation) should be considered morally correct per se. Indeed, as we have seen, he even warned against the danger of an aberrant practice of self-cultivation that is carried out under the false pretext of moral education. What is more, the dialectical analysis of the lust for power demonstrates that the "deepest" (voluntary) obedience is paid to a will that functions as a model of moral exemplarity. Here, too, one might therefore argue that morality remains closely intertwined with ulterior power-related issues. Yet, moral intuition emerges in the vacuity of the "void potency [and] bright awareness," and connotes a solitary, spiritual self-transgression of the subjective mind. This is the very point at which Tang departed from Nietzsche: Because moral intuition is situated in the state of spiritual vacuity, it is, in fact, detached from any intersubjective practice, whether or not it is dominated by the lust for power. It can only be speculated why Tang did not discuss Nietzsche's philosophy of power in-depth, and it is also unclear whether he ever even studied the German philosopher. ${ }^{58}$ Perhaps his silence on Nietzsche is due to an implicit trait in his civil theology which tends to ignore incommensurable ideas, trusting instead that they, in the worst case, turn out to be temporary stumbling blocks along the spiritual path to the realm of self-fulfillment.

With its skepticism towards claims about an allegedly superior, traditional ethics, Tang's reflection on power has repercussions for his notion of self-cultivation. For one, self-cultivation, which requires the practitioner to "understand his own nature (zhi qi xing)," inevitably entails the danger that the diabolic side of human nature manifests itself, in either explicit or hidden form. After all, self-cultivation inevitably takes place under the condition of the subject's inextricable absorption with the lust for power and hence cannot

$5^{8}$ Tang's diaries from 1948 onwards, in which he listed his readings with minutely detail, do not give any hint at an intensive study of Nietzsche. In the context of his reflection about power, Tang mentions Nietzsche only in passing, once negatively, at another point more affirmatively. For an affirmative statement, see Tang's article "The sources of humanity's evil" (in: Tang, Zhonghua renwen yu dangjin shijie bubian, Vol. 10, p. 110); for a critical reference, see Tang, Renwen jingshen zhi chongjian, p. 565 . 
be considered immune from moral failure. Indeed, it is the awareness of a tension between essence (moral nature; xing) and existence (in a reality marked by manifold power-relations, most of all in political life) which sustains the continuing effort of self-cultivation: Individuals should neither presume that they embody unlimited goodness and perfection, nor that their actions are thoroughly characterized by purely moral motivations, morally correct reasoning, and morally fully accountable effects. Tang therefore criticized his Confucian predecessors for falsely believing that political activity (i.e. existence) can be turned into an "immediate extension of the moral consciousness" (i.e. essence). ${ }^{59} \mathrm{~A}$ moral consciousness may enable the human being to strive for the ethical good in politics, but it does not necessarily allow him or her to eliminate evil. ${ }^{60}$ Human beings must brace themselves for the bleak prospect that their political will cannot offer any guarantee for the realization of moral goals by the use of moral means. Tang resisted here the wide-spread Confucian belief that human beings can realize political and social ideals, provided that their choice of means and aims truly conforms to the standards of a higher (Heavenly) order-or, as seen from another perspective, the claim that human beings who fail to realize political and social ideals apparently erred in their conception of the highest good in the first place. Tang, for his part, did not share the basic assumption of this belief, namely, that the intensity of the "ought" (aspired to by the moral will) determines the very reality in which the human will exists. Such an ideologically loaded moral ontology, by the way, has not lost its attractiveness in Confucianism today. A tell-tale sign is the peculiar type of appellative Confucian rhetoric with which some proponents of Confucianism express their conviction that the successful implementation of their ideas immediately depends on the intensity of the moral will (as expressed by their urgency of their appeal to the reader).

Tang rejected the conceptualization of the political as an extension of morality not only because it weakens the defenses of modern Confucianism against political ideologies. There is also the fact that in the ideologically distorted vision of a thoroughly moralized, depoliticized reality, "moral efforts" by individuals are bound to disappear altogether, for there would no longer be a reason to strive for moral self-improvement in a perfect world. This would clearly contradict Tang's liberal credo that each individual must take up his or her own personal struggle for moral integrity. If the individual abandons this

\footnotetext{
59 Tang, Renwen jingshen zhi chongjian, p. 419.

6o Ibid., p. 396. In another passage, Tang stated that the "evil" in politics might be "reduced" - though, tellingly, he did not claim that evil may be eliminated for good; see Tang, Zhonghua renwen yu dangjin shijie bubian, Vol. 10, pp. 114-115.
} 
struggle, nothing less than the "death of the humanistic world" is at stake. Any opportunity to establish a humanistic world of the "highest harmony" would be forsaken, because harmony and relations of "mutual excitation" (xiang gan 相感) between individuals require the possibility of "deviation." The ideal humanistic world is therefore different from a world of "great uniformity" (da tong), in which the political nature of the human being would be eliminated for good in favor of a new man who is perfectly rational and virtuous. ${ }^{61}$ Tang obviously criticized here Kang Youwei's vision of a future world of great uniformity. But he also more than likely turns against the totalitarian ideology in the PRC, and perhaps also against the ideology of the GMD, for it was, after all, Sun Yat-sen who vehemently upheld the ideal of a great uniformity in his Three Principles of the People. ${ }^{62}$

\footnotetext{
61 Tang, Renwen jingshen zhi chongjian, p. 71.

62 Sun, San minzhuyi, p. 5 o.
} 